\title{
Apakah Penerapan Standar Akuntansi, Kompetensi Sumberdaya Manusia serta Peran Auditor Internal mempengaruhi Kualitas Laporan Keuangan?
}

\author{
Nur Kabib $^{1)}$, Siti Nur Hayati ${ }^{2)}$, Siti Fatimatuzzahra ${ }^{3)}$ \\ ${ }^{1,2,3}$ Akuntansi Syariah, IAIN Salatiga, Indonesia \\ *Email korespondensi: nurkabib@ iainsalatiga.ac.id
}

\begin{abstract}
This study aims to analyze the application of government accounting standards, human resource competence, and the role of auditors on the quality of the financial reports of the Salatiga City government. The research method used in this research is quantitative research. The criteria of the respondents in this study were all government officials who were involved and technically involved in the management and preparation of financial reports in the Salatiga City Government agencies. The data were processed using multiple linear regression tests with the SPSS software tool. The results of this study prove that all independent variables have a significant positive effect on the dependent variable, parsia; and simultaneously.
\end{abstract}

Keywords: Government Accounting Standards, Human Resources, Role of Internal Auditors, Quality of Financial Statements

Saran sitasi: Kabib, N., Hayati, S. N., \& Fatimatuzzahra, S. (2021). Apakah Penerapan Standar Akuntansi, Kompetensi Sumberdaya Manusia serta Peran Auditor Internal mempengaruhi Kualitas Laporan Keuangan?. Jurnal Akuntansi dan Pajak, 21 (2), 473-481. doi: http://dx.doi.org/10.29040/jap.v21i2.1335

DOI: http://dx.doi.org/10.29040/jap.v21i2.1335

\section{PENDAHULUAN}

Financial statements merupakan dokumen bisnis yang dipakai perusahaan maupun organisasi public guna melaporkan output aktivitas kepada semua pihak yang berkepentingan, yang meliputi kreditur, manajer, agen regulator dan investor maupun pemerintah. Informasi yang ada dalam pelaporan keuangan harus berkualitas sehingga bisa digunakan sebagai alat pengambilan keputusan oleh para calon investor dan pengguna lainnya. Karakteristik mengenai kualitas pelaporan keungan terdiri dari karakteristik kualitatif laporan keuangan yang merupakan instrument untuk dijadikan informasi dalam seperangkat laporan keuangan yang memiliki manfaat bagi penggunanya. Di dalam Conseptual framework IFRS, terdapat empat prinsip karakteristik kualitatif pelaporan keuangan tersebut yaitu dapat dipahami, relevan, dapat dipercaya (dapat diandalkan) dan dapat diperbandingkan.Kulaitas laporan keuangan Pemerintah Daerah masih perlu ditingkatkan, sebagaimana Badan Pengawas Keuangan dan Pembangunan (BPKP) meneyeknggarakan kongres peningkatan kualitas laporan keuangan bagi
Pemerintah Daerah dengan SIMDA aplikasi pendukungnya (BPKP, 2010).

Quality of local government financial reportsmerupakan sebuah tuntutan publik untuk pemerintahan.Peraturan Pemerintah (PP) No. 58 Tahun 2005 terkait Pengelolaan Keuangan Daerah menjelaskan tentang kewajiban Pemerintah Daerahmenyusun suatu kebijakan akuntansi. Di dalam PP No. 58 Tahun 2005 tersebut menjelaskan tentang arti dari keuangan daerah sebagai semua hak dan kewajiban suatu daerah dalam penyelenggaraan kegiatan Pemerintah Daerah yang berkaitan dengan uang termasuk segala bentuk kekayaan daerah(Peraturan Pemerintah, 2005). Statement of Financial Accounting Concept (SFAC) No. 2 menjelaskan tentang karakteristik laporan keuangan guna menilai kualitas pelaporan keuangan, seperti : Relevan, Reliability (Keandalan), Daya Banding dan Konsistensi, Pertimbangan Cost-Benefit, Materialitas Karakteristik.

Begitupula Standar Akuntansi Pemerintah (SAP) Indonesia yakni, andal, relevan,dapat dipahami dan dapat dibandingkan(Peraturan Pemerintah, 2010). Hal ini menunjukkan bahwa Pemerintah Daerahharus 
mampu menciptakan akuntabilitas dan transparansi dalam hal pengelolaan keuangan daerah. Sistem akuntansi pemerintah dapat dikatakan sudah baik ketika dapat merealisasikan tujuan pemerintahan bersih (clean goverment), kebijakan keuangan daerah disusun secara ekonomis, efisien, efektif, transparan dan akuntabel. Suatu sistem pertanggungjawaban keuangan dari sebuah institusi akan berjalan baik, jika ada mekanisme pengelolaan keuangan yang baik pula (Mardiasmo, 2018).

Peneliti yang telah membahas terkait kualitas laporan keuangan terhadap kualitas laporan keuagan telah dilakukan beberapa penelititi (Pinto, Morais, \& Quick, 2020), (Wineh, Ferdian, \& Novianti, 2019). Secara spesifik Penerapan Standar Akuntansi Pemerintahan Terhadap Kualitas Penyajian Laporan bahwa penerapan SAP memiliki pengaruhpositif terhadap kualitas laporan keuangan DPPKAD Kabupaten Gorontalo (Sako \& Lantowa, 2018).

Pada pasal 15 ayat (1) UU No. 15 tahun 2004 menjelaskan bahwa pemeriksa (BPK) membuat laporan hasil pemeriksaan (LHP) sesudah selesai melakukan pemeriksaan. Dan pasal 16 ayat (1) UU No. 15 tahun 2004 menjelaskan bahwa LHP atas laporan keuangan pemerintah berisi tentang sebuah opini. Opini merupakan sebuah pernyataan yang profesional sebagai sebuah kesimpulan dari proses pemeriksaan terkait tingkat kewajaran dari suatu informasi yang telah disajikan di laporan keuangan. Saat melakukan pemeriksaan laporan keuangan, BPK harus menilai dan menguji SPI pemeritah daerah terlebih dahulu. Pemeriksa melakukan pengujian dan penilaian atas pelaksanaan sistem pengendalian intern pemerintahdilakukan dalam pemeriksaan sebagaimana tercantum dalam pasal 12 . Tujuan dari SPI sendiri adalah untuk meningkatkan kualitas pelaksanaan pemeriksaan keuangan yang telah dilakukan oleh pihak BPK dan bagi pihak pemda yang berguna untuk mengevaluasi sistem pengendalian dan kinerja pemeriksaan intern. Menurut UU No. 15/2004 terkait Pemeriksaan Tanggung Jawab dan Pengelolaan Keuangan Negara, ada empat opini yang disampaikan BPK yakni: opini Wajar Tanpa Pengecualian (WTP), opini Wajar Dengan Pengecualian (WDP), opini Tidak Wajar (TP), dan Pernyataan Menolak memberi opini.

Dalam rangka pengimplementasian Peraturan Menteri Dalam Negeri(Permendagri) nomor 132006 yang telah diubah pada Peraturan Menteri Dalam Negeri (Permedagri nomor 212011 terkait Perubahan
KeduaPermendagri Nomor. 13 n 2006 terkait Pedoman Pengelolaan Keuangan Daerah, maka Pemerintah Daerah memilikikewajiban mempersiapkan diri untuk melaksanakan pengelolaan keuangan sesuai peraturan yang sudah ada.Maka Pemerintah Daerah didiwaibkan untuk melakukan perbaikan diribaik dalam hal sumber daya manusia (SDM) maupun hal lain yang berhubungan dengan pelaksanaan tersebut. Berkiatan dengan standar akuntansi dibuat hipotesis alternative sebagai berikut. H1 : Penerapkan standar akuntansi pemerintah yang baik dapat berpengaruh positif terhadap kualitas laporan keuangan daerah.

Kompetensi sumber daya manusia diperoleh melalui proses pembelajaran. Dalam kegiatanpembelajaran, memungkinkan seorang individu memperoleh bermacam-macam pengertian, keterampilan, kecakapan,sikap dan perilaku. Belajar memiliki peranan pentingdalam melanjutkan kompetensi dankebudayaan kepada para generasi penerus bangsa. Guna menyusun laporan keuangan berkualitas, maka diperlukan kompetensi sumber daya manusia memadai. Hal ini menjelaskanbahwa kompetensi pegawai pengelola keuangan memiiki pengaruh terhadap kualitas laporan keuangan(Fikri, Made, \& Wirshandono, 2016).

Kompetensi sumberdaya manusia (SDM) (Sudarmanto, 2015)terdiri atas Motive (dorongan), Traits (ciri, sifat,karakter pembawaan), Self image (citra diri), Social role (peran sosial), maupunSkills (keterampilan).Kompetensi SDM, perangkat pendukung dan peran auditor internal memiliki pengaruh positif terhadap kualitas laporan keuangan Pemerintah Daerah Kabupaten Kerinci, dan faktor paling mendominasi yaitu kompetensi SDM(Lasmara \& Rahayu, 2016), (Wineh et al., 2019).Berdasarkan penjelasan-penjekasan tersebut, maka peneliti membuat dugaan sementara tentang sumber daya manusia (SDM) yang dinyatakan dalam pernyataan hipotesis sebagai berikut:

$\mathrm{H} 2$ : Kompetensi SDM yang semakin tinggi memiliki pengaruh positif terhadap kualitas laporan keuangan daerah.

Audit internaladalah suatu aktivitas konsultasi yang memastikan tercapainya sebuah tujuan yang telah dirancang guna menambah serta meningkatkan operasi suatu organisasi. Audit internal dapat membantu suatu organisasi dalam mencapai visi misi melalui tahappengevaluasian guna meningkatkan efektifitas pengendalian, proses manajemen risiko dan 
manajemen. Keefektifan audit internal dibutuhkan untuk perencanaan serta pelaporan yanghasilnya dapat dievaluasi oleh pihak komite audit. Fungsi audit internaladalah sebagai suatu sumberinformasi independen terkait aktivitas organisasi dan sebagai dasar penentuan keputusan yang accountabledan obyektif. Auditor internal terlibat dalam proses pelaporan keuangan dan berperan aktif dalam menciptakanpraktik corporate governance yang baik. Audit internal memiliki peran mengawasi manajemen yang bekerjasama dengan komite audit.

Auditor intern bekerja dalam perusahaan untuk melakuan pengauditan tentang audit manajmen. Laporan audit manajemen biasanya berguna untuk manajemen perusahaan yang diaudit (Erfiansyah \& Kurnia, 2018).Audit internal merupakan mekanismedalam mengatasi kemungkinan munculnya resiko akibat semakin meningkatnya laju perkembangan teknologi. audit internal merupakan aktivitas yang secara independen dan objektif menjamin kualitas laporan keuangan. Selain itu, audit internalmerupakan jasa konsultasi yang dibuatguna menghasikan nilai tambah serta meningkatkan kinerja operasi suatu organisasi(Kurniawan, 2015), (Du, Yin, \& Hou, 2018).

Audit internal adalah aktivitasyang dilakukan guna membantu manajemen untuk menyediakan sebuah informasi, dimana tujuanakhirmenambah nilai dari perusahaan. Audit internal harus dilakukan secara obyektif dan independen atau dengan kaa lain tidak dapat dipengaruhi pihak lain dan tidak terlibat langsung dalam penyusunan laporan keuangan yang diaudit. Hasil pengauditan yang dilakuukan oleh audit internal secara obyektif dan independen dapat diandalkanoleh Stake Holder (Suherman, 2018). Penelitin yang lain juga menyatakan bahwa auditorinternalmemiliki pengaruh signifikan terhadap kualitas laporan keuangan(Abbott, Daugherty, Parker, \& Peters, 2016)(Gros, Koch, \& Wallek, 2017)(Amalia \& Lukito, 2014), (Gras-Gil, Marin-Hernandez, \& de Lema, 2012), (Johl, Kaur Johl, Subramaniam, \& Cooper, 2013). Berkaitan dengan audit internal dibuat hipotesis alternative sebagai berikut.

H3 : Keterlibatan auditor internal dalam pengawasan keandalan dari laporan keuangan meningkatkan kualitas pelaporan keuangan.

Laporan Keuangan Pemerintah Daerah (LKPD) Kota Salatiga selama 3 tahun berturut-turut mendapatkan opini tanpa Pengecualian (WTP). Untuk memperoleh informasi keuangan yang berguna bagi para stake holder, maka laporan keuangan harus dibuat sesuai dengan sistem akuntansi keuangan Pemerintah Daerah dan pegawai pemeritah harus memiliki kompetensi dalam bidang pengelolaan keuangan daerah dan juga sistem akuntansi (Yusniyar, Darwanis, \& Abdullah, 2016).

Penelitian ini mencoba mengungkap hubungan antara penerapan Standar Akuntansi Pemerintah, kompetensi sumber daya manusia dan peran auditor internal dan kualitas laporan keuangan Pemerintah Kota Salatiga. Berdasarkan limitasi pengetahuan tentang hal tersebut, maka dari itu peneliti berniat meneliti lebih lanjut tentang Pengaruh Penerapan Standar Akuntansi Pemerintah, Kompetensi Sumberdaya Manusia Dan Peran Auditor Internal Terhadap Secara simultan semua variable independen diduga mempengaruhi variable dependen yang dinyatakan dengan hipoteiss alternative sebagai berikut

H4 : Kualitas laporan keuangan dipengaruhi oleh penerapan standar akuntansi pemerintah, kompetensi sumberdaya manusia dan peran auditor internal.

Merujuk pada penelitian pendahuluan, konsep dan teori di atas, maka kerangka pemikiran pada penelitian ini digambarkan sebagai berikut :

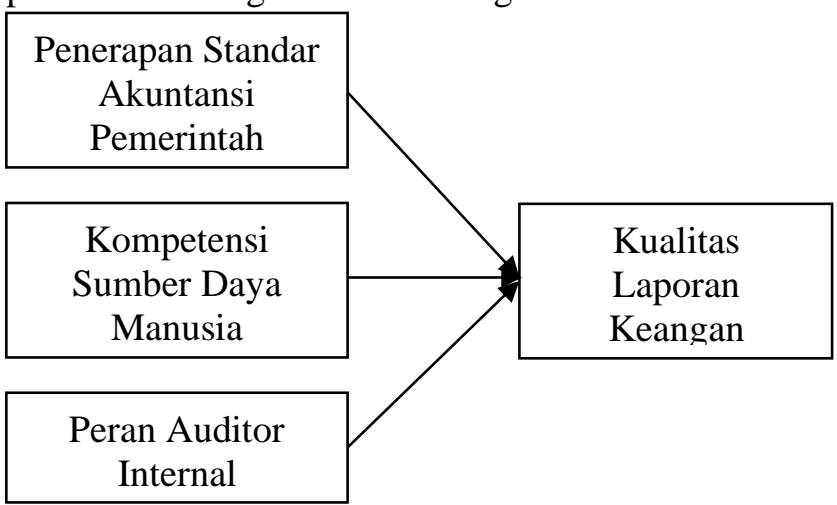

\section{METODE PENELITIAN}

Penelitian pada dasarnya dilakukan untuk menunjukan kebenaran dan pemecahan masalah atau topik yang sedang diteliti. Untuk mencapai suatu tujuan, maka dipakailah suatu metode yang relevan dantepat guna mencapai tujuan tersebut. Metode penelitian merupakan suatu cara ilmiah guna memperoleh data untuk tujuan dan manfaat tertentu. Pada penelitian ini, metode penelitian yang penulis gunakanadalah penelitian kuantitatif (Sugiyono, 2017). 


\section{a. Objek}

Objek penelitian adalah suatu yang akan menjadi pusat perhatian didalam sebuah penelitian, atau demham kata lain objek penelitian akan menjadi target dalam suatu penelitian guna memperoleh jawaban maupun solusi dari satu permasalahan tersebut. Objek penelitian adalah target ilmiah guna memperolehdata untuk tujuan dan manfaat tertentu tentang sesuatu hal objektif, valid dan reliable tentang suatu hal (variabel tertentu). Objek penelitian yang diteliti pada penelitian ini adalah Standar Akuntansi Pemerintah (X1), Kompetensi Sumberdaya Manusia (X2), Peran Auditor Internal (X3) dan Kualitas Laporan Keuangan Pemerintah (Y). Sedangkan subjek dalam penelitian ini yaitu Pemerintah Kota Salatiga. Penelitian ini memiliki tujuan guna mengetahui apakah penerapan standar akuntansi pemerintah, kompetensi sumberdaya manusia dan peran auditor internal memiliki pengaruh terhadap kualitas laporan keuangan pemerintah kota Salatiga.

\section{b. Bahan dan alat utama}

Alat yang digunakan dalam penelitian ini yaitu pedoman observasi, pedoman angket. Pedoman Observasi, Alat bantu yang digunakan peneliti ketika mengumpulkan data melalui pengamatan dan pencatatan terhadap fenomena yang diselidiki. Pedoman Angket, Alat bantu berupa pernyataan yang harus dijawab oleh responden. Angket merupakan alat utama dalam penelitian ini.

\section{c. Tempat}

Penelitian ini dilaksankan di Bagian Akuntansi Pemerintahan Kota Salatiga tahun 2019.

\section{d. Teknik pengumpulan data}

Teknik pengumpulan data pada penelitian ini adalah penelitian lapangan. Metode yang digunakan adalah metode survei. Adapun teknik yang dipakaipada penelitian ini yaitu teknik kuesioner secara langsung kuesioner disampaikan dan dikumpulkan langsung oleh peneliti dari staf pemerintah kota Salatiga. Data primer diperoleh melalui penyebaran kuesioner menggunakan skoring untuk masing-masing pernyataan.

\section{e. Definisi operasional variabel penelitian}

Variabel yang dipakai pada penelitian ini adalah variabel bebas dan variabel terikat.

1) Variabel Bebas (Independent Variable)

Variabel independen merupakan variabel yang mempengaruhi atau menyebabkan timbulnya atauperubahan dari variabel dependen(Sugiyono,
2017).Variabel bebas yang dipakaipada penelitian ini adalah ;

a) Penerapan Standar Akuntansi Pemerintah SAP)

Variabel penerapan standar akuntansi pemerintahan diukur dengan 11 indikator yaitu: Penyajian Laporan Keuangan, Laporan Realisasi Anggaran, Laporan Arus Kas, Catatan atas Laporan Keuangan, Akuntansi Persediaan, Akuntansi Investasi, Akuntansi Aset Tetap, Akuntansi Kontruksi dalam Pengerjaan, Akuntansi Kewajiban, Koreksi Kesalahan, Laporan Keuangan Konsolidasi

b) Kompetensi Sumber Daya Manusia (SDM) Variabel kompetensi sumber daya manusia diukur dengan 3 indikator yaitu: pengetahuan, keahlian, maupun perilaku.

c) Peran Auditor Internal

Variabel Peran Auditor Internal diukur dengan 3 indikator yaitu : Audit internal meninjau kepatuhan Pemerintah Daerah terhadap peraturan perundang-undangan yang berlaku, Audit internal memeriksa tingkat ketetapan dan keandalan laporan keuangan, Audit internal membeikan rekomendasi dan pendampingan pada pemerintah

2) Variabel Terikat (Dependent Variable)

Variabel terikat yang digunakan dalam penelitian ini yaitu kualitas laporan keuangan pemerintah. Indikator laporan keuangan relevan, andal, dapat dibandingkan dan dapat dipahami.

\section{f. Teknik Analisis}

Regresiinier berganda merupakan teknik yang digunakan dalam penelitian ini. SPSSmerupakan alat bantu untuk melakukan uji uji instrumen, uji asumsi maupun uji hipotesis. Data yang didapat dari responden dengan kuesioner yang telah dilakukan uji validitas maupun reliabilitas. Uji validitas dipakai guna mengetahui alat ukur yang telah disusun dapat mengukur sesuatu yang perlu diukur. Teknik pengujian validitas menggunakan teknik korelasi Product-Moment coefficient dari Pearson. Dan uji reliabilitas memiliki tujuan untuk melihat alat ukur yang dipakai menggambarkan tingkat konsistensi, keakuratan,ketepatan dan kestabilan dalam menunjukkan gejala tertentu sekelompok individu, meskipun dilakukan pada kurun waktu yang berbeda. Pengujian reliabilitas pada penelitian ini memakaiCronboach alpha dari masing-masing instrumen. 


\section{Jurnal Akuntansi dan Pajak, 21 (02), 2021, 477}

\section{HASIL DAN PEMBAHASAN}

\subsection{Hasil penelitian}

Uji Instrumen Data

Dalam penelitian ini, data diuji menggunaan uji validitas dan uji reliabilitas untuk menguji instrumrn data. Data diperoleh dari pendistribusian kuisioner kepada 30 petugas akuntansi yang ada di pemerintahan kota salatiga. Hasil analisis uji validitas dan reliabilitas dari data tersebut digunakan sebagai patokan untuk menuju anaisis berikutnya. Kualitaslaporan keuanganPemerintah Daerah,penerapanstandar akuntansi pemerintah, kompetensi sumberdayamanusia, peran auditor internal merupakan elemen-lemen yang diukur. Hasil uji Validitas dan Reliabilitas adalah sebagai berikut: a. Uji Validitas

Tabel 1.

Uji validitas Instrumen untuk Variabel Kualitas Laporan Keungan Pemerintah Daerah

\begin{tabular}{lllc}
\hline No Item & r-hitung & $\mathrm{r}$ - tabel & Valid \\
\hline KLK 1 & 0,901 & 0,361 & Ya \\
KLK 2 & 0,865 & 0,361 & Ya \\
KLK 3 & 0,849 & 0,361 & Ya \\
KLK 4 & 0,823 & 0,361 & Ya \\
KLK 5 & 0,825 & 0,361 & Ya \\
KLK 6 & 0,825 & 0,361 & Ya \\
KLK 7 & 0,936 & 0,361 & Ya \\
KLK 8 & 0,823 & 0,361 & Ya \\
\hline
\end{tabular}

\section{Sumber: Hasil Olah Data, 2019}

Tabel tersebut menunjukkan bahwa nilai $r$ hitung $>\mathrm{r}$ tabel dari seluruh butir pertanyaan tentang kualitas laoran keuangan Pemerintah Daerah. Sehingga dapat disimpulkan bahwa semua butir pertanyaan adalah valid.

Tabel 2.

Uji validitas Instrumen untuk Variabel Penerapan Standar Akuntansi Pemerintah

\begin{tabular}{llll}
\hline No Item & r-hitung & r-tabel & Valid \\
\hline SAP1 & 0,801 & 0,361 & Ya \\
SAP2 & 0,796 & 0,361 & Ya \\
SAP3 & 0,760 & 0,361 & Ya \\
SAP4 & 0,932 & 0,361 & Ya \\
SAP5 & 0,474 & 0,361 & Ya \\
SAP6 & 0,845 & 0,361 & Ya \\
SAP7 & 0,723 & 0,361 & Ya \\
SAP8 & 0,884 & 0,361 & Ya \\
SAP9 & 0,926 & 0,361 & Ya \\
SAP10 & 0,773 & 0,361 & Ya \\
SAP11 & 0,793 & 0,361 & Ya \\
\hline
\end{tabular}

Sumber: Hasil Olah Data, 2019
Tabel tersebut menunjukkan bahwa nilai $\mathrm{r}_{\text {hitung }}>$ $\mathrm{r}_{\text {tabel }}$ dari seluruh butir pertanyaan tentang penerapan standar akuntansi pemerintah. Sehingga dapat disimpulkan bahwa semua butir pertanyaan adalah Ya.

Tabel 3.

Uji validitas Instrumen untuk Variabel Kompetensi Sumber Daya Manusia

\begin{tabular}{llll}
\hline No Item & r-hitung & r-tabel & Valid \\
\hline KSDM 1 & 0,763 & 0,361 & Ya \\
KSDM 2 & 0,683 & 0,361 & Ya \\
KSDM 3 & 0,601 & 0,361 & Ya \\
KSDM 4 & 0,511 & 0,361 & Ya \\
KSDM 5 & 0,446 & 0,361 & Ya \\
\hline
\end{tabular}

Sumber: Hasil Olah Data, 2019

Tabel tersebut menunjukkan bahwa nilai $\mathrm{r}_{\text {hitung }}>$ $r_{\text {tabel }}$ dari seluruh butir pertanyaan tentang kompetensi sumber daya manusia. Sehingga dapat disimpulkan bahwa semua butir pertanyaan adalah Ya.

Tabel 4.

Uji validitas Instrumen untuk Variabel Peran Auditor Internal

\begin{tabular}{llll}
\hline No Item & r-hitung & r-tabel & valid \\
\hline PAI 1 & 0,492 & 0,361 & Ya \\
PAI 2 & 0,702 & 0,361 & Ya \\
PAI 3 & 0,644 & 0,361 & Ya \\
\hline
\end{tabular}

Tabel tersebut menunjukkan bahwa nilai $\mathrm{r}_{\text {hitung }}>$ $r$ tabel dari seluruh butir pertanyaan tentang peran auditor internal. Sehingga dapat disimpulkan bahwa semua butir pertanyaan adalah Ya.

b. Uji Reliabilitas

Tabel 5.

Hasil Reliabilitas

\begin{tabular}{|c|c|c|}
\hline Variabel & $\mathrm{r}$ alpha $\mathrm{r}$ tabe & Reliabel \\
\hline Kualitas_Lap._Keu._Pemda & $0,794 \quad 0,60$ & Ya \\
\hline Penerapan_SAP & 0,775 & Ya \\
\hline Kompetensi_SDM & 0,733 & $\mathrm{Ya}$ \\
\hline Peran_Audit_Internaal & 0,704 & $\mathrm{Ya}$ \\
\hline
\end{tabular}

Sumber: Hasil Olah Data, 2019

Berdasarkan tabel diatas baik variabel dependen maupun independen adalah reliabel karena memiliki nilai alpha >0,6. Sehingga dapat dipakai untuk mengolah data berikutnya

c. Uji Hipotesis

1) Analisis Regresi Linier Berganda

Analisis regresi linier berganda ini dipakai untuk mengetahui pengaruh antara variabel independen dan dependen. Dalam melakukan pengujian, peneliti menggunakan alat bantu program SPSS 23.00. Berdasarkan hasil uji analisis regresi 


\section{Jurnal Akuntansi dan Pajak, 21 (02), 2021, 478}

linierberganda menggunakan program SPSS, maka hasilnya dapat dilihatdari tabel dibawah ini:

Tabel 6

Hasil Uji R2

\begin{tabular}{|c|c|c|c|c|}
\hline Model & $\mathrm{R}$ & $\begin{array}{c}\mathrm{R} \\
\text { Square }\end{array}$ & $\begin{array}{l}\text { Adjusted } \\
\text { R Square }\end{array}$ & $\begin{array}{l}\text { Std. Error of the } \\
\text { Estimate }\end{array}$ \\
\hline 1 & 0,904 & 0,817 & 0,796 & 1,499 \\
\hline
\end{tabular}

\section{Sumber: Hasil Olah Data, 2019}

Dari hasil pengujian diketahui nilai koefisien determinasi (adjusted R2) sebesar 0,796, hal ini berarti bahwa variabel independen dalam menjelaskan variasi kualitas laporan keuanganPemerintah Daerah kota Salatiga sebesar 79,6\%. Dengan demikian sisanya $20,4 \%$ dijelaskan oleh faktor-faktor lain atau variabel lain diluar modal.

2) Uji F

Uji F dipakai guna menguji apakah variabel independen memiliki pengaruh secara signifikan terhadap variabel dependen saat diuji secara bersamaan. Berikut data hasil pengujian :

Tabel 7

Hasil Uji F

\begin{tabular}{llll}
\hline $\mathrm{F}_{\text {hitung }}$ & $\mathrm{F}_{\text {tabel }}$ & Sig & Keterangan \\
\hline 38,706 & 2,98 & 0,000 & $\begin{array}{l}\text { Berpengaruh secara } \\
\text { simultan }\end{array}$ \\
\hline
\end{tabular}

\section{Sumber: Hasil Olah Data, 2019}

Berdasarkan hasil pengujian variabel kualitas laporan keuangan Pemerintah Daerahdiperoleh nilai $F$ hitung 38,706 dengan $p$-value $=0,000$, dan $\mathrm{F}$ tabel 2,98. Ketentuan $\alpha=5 \%, \mathrm{df}=\mathrm{k}-1$ atau 4 $1=3$, dan df $2=n-k$ atau 30-4 $=26$, hasil uji dari distribusi $\mathrm{F}$ hitung 38,706 lebih besar dari $\mathrm{F}$ tabel 2,98 dengan $\mathrm{p}$-value $0,000<0,05$. Dengan demikian simpulan tentang model penelitian sudah fit of goodness.

d. Uji t

Berdasarkan hasil analisis dapat diketahui hasil uji t pada tabel berikut:

\section{Tabel 9}

Hasil Uji T

\begin{tabular}{lcccc}
\hline Variabel & $\mathrm{T}_{\text {hitung }}$ & $\mathrm{T}_{\text {tabel }}$ & $\mathrm{Sig}$ & Keterangan \\
\hline (Constant) & 1,431 & 2,056 & 0,164 & \\
Penerapan SAP & 7,286 & 2,056 & 0,000 & $\mathrm{H} 1$ Diterima \\
Kompetensi SDM & 2,020 & 2,056 & 0,045 & $\mathrm{H} 2$ Diterima \\
Peran Audit & $-2,885$ & 2,056 & 0,008 & H3 Diterima \\
Internal & & & & \\
Sula & & & &
\end{tabular}

Sumber: Hasil Olah Data, 2019
Dari hasil perhitugan diperoleh beberapa kesimpulan yaitu :

1) Penerapan SAP (X1)

Dalam kolom coeficients model 1 menunjukan bahwa nilai sig 0,000 . Ketika nilai sig lebih kecil dari nilai probabilitas 0,05 maka $\mathrm{H} 1$ diterima. Variabel penerapan SAP (X1) memiliki t hitung sebesar 7,286 dan t tabel sebesar 2,056. Disini $t$ hitung $>t$ tabel yang menunjukkan bahwa variabel $\mathrm{X} 1$ memiliki kontribusi terhadap variabel $\mathrm{Y}$. X1 memiiki pengaruh signifikan positif terhadap $\mathrm{Y}$

2) Kompetensi SDM (X2)

Dalam kolom coeficients model 1 menunjukan bahwa nilai sig 0,045. Ketika nilai sig lebih kecil dari nilai probabilitas 0,05 maka $\mathrm{H} 2$ diterima. Variabel Kopetensi SDM (X2) memiliki t hitung sebesar 2,020 dan t tabel sebesar 2,056. Disini t hitung $>t$ tabel yang menunjukkan bahwa variabel X2 memiliki kontribusi terhadap variabel Y. X2 memiiki pengaruh signifikan positif terhadap $\mathrm{Y}$

3) Peran Audit Internal

Dalam kolom coeficients model 1 menunjukan bahwa nilai sig 0,008 . Ketika nilai sig lebih kecil dari nilai probabilitas 0,05 maka $\mathrm{H} 3$ diterima. Variabel Peran audit internal (X3) memiliki t hitung sebesar -2,889 dan $\mathrm{t}$ tabel sebesar 2,056. Disini t hitung $>\mathrm{t}$ tabel yang menunjukkan bahwa variabel X3 memiliki kontribusi terhadap variabel $\mathrm{Y}$. X3 memiiki pengaruh signifikan negatif terhadap $\mathrm{Y}$.

\subsection{Pembahasan}

\section{a. Penerapan Standar Akuntansi Pemerintah dan KualitasLaporan Keuangan Pemerintah Daerah}

SAP merupakan prinsip akuntansi yang digunakan untuk membuat dan menyajikan laporan keuangan pemerintah. Pemerintah harus menerapkan SAP dengan benar guna menghaikan laporan keuangan yang berkulitas dan sesuai dengan SAP. Penerapan Standar Akuntansi Pemerintahan (SAP) adalah pelakanaanprinsip akuntansi termasuk semua siklus dan tahapan hingga seperti penyajian laporan keuangan untuk memperoleh hasil laporankeuangan yang berkualitas. Maka dari itu ketika akuntansi diaplikasikan sesuai standar akuntansi maka laporan keuangan Pemerintah Daerahyang dihasilkan pasti berkualitas.

Hipotesis pertama diterima. Artinya, sistem akuntansi pemerintahan memiliki pengaruh positif 
terhadap kualitas laporan keuangan. Sama halnya dengan fakta dan data yang diperoleh peneliti bahwa penerapan standar akntansi pemeritahberpengarh terhadap kualitas laporan keuangan. Hasil pengujian hipotesis menunjukkan bahwanilai koefisien regresi $\beta 1 \neq 0$. Hal ini menunjukkan bahwa semakin baik penerapan standar akuntansi pemerintahan maka kualitas laporan keuangan suatuPemerintah Daerah akan semakin baik pula. Penelitian secara parsial menunjukkan bahwa penerapan SAP memiliki nilai sebesar 0,600, hal ini menunjukkan bahwa setiap terjadi peningkatan pada penerapan SAP dalam skala interval akan meningkatkan kualitas laporan keuangan SKPD kota salatiga sebesar 0,600 satuan pada skala interval. Dalam kolom coeficients model 1 menunjukan bahwa nilai sig 0,000 . Ketika nilai sig lebih kecil dari nilai probabilitas 0,05 maka H1 diterima. Variabel penerapan SAP (X1) memiliki t hitung sebesar 7,286 dan $t$ tabel sebesar 2,056. Disini $\mathrm{t}$ hitung $>\mathrm{t}$ tabel yang menunjukkan bahwa variabel $\mathrm{X} 1$ memiliki kontribusi terhadap variabel Y. X1 memiiki pengaruh signifikan positif terhadap $\mathrm{Y}$.

Hasil penelitian ini konsisten dengan hasil penelitian yang dilakkan oleh (Munasyir, 2015), (Yusniyar et al., 2016), (Sako \& Lantowa, 2018)yang menunjukkanbahwa penerapan standar akuntansi pemerintahan berpengaruh positif terhadapkualitas laporan keuangan pemerintah.

\section{b. Kompetensi Sumberdaya Manusia dan Kualitas LaporanKeuangan Pemerintah Daerah}

Kompetensi SDM adalah kemampuan kerja seorang individu yang meliputi aspek pengetahuan, keahlian dan periaku kerja sesuaistandar yang telah ditetapkan.Kompetensi sumber daya manusia memiiki pengaruh terhadapkualitas laporan keuangan. Dengan kata lain bahwaketika kompetensi sumber daya manusia memilki kualitas yang baik maka hal ini akan menunjang kualias laporan keuangan lebih baik.Dalam penyusunan sebuah laporan keuangan yangberkualitas dibutuhkan SDM yang paham akan standar penyusunan laporankeuangan.Sehingga proses penyusunan laporan keuangan akan berjalan denganefektif dan efisien.

Hipotesis kedua diterima. Artinya, kompetensi sumber daya manusia memiliki pengaruh positif terhadap kualitas laporan keuangan. Sama halnya dengan fakta dan data yang diperoleh peneliti bahwa kompetensi sumber daya manusiaberpengarh terhadap kualitas laporan keuangan. Hasil pengujian hipotesis menunjukkan bahwa nilai koefisien regresi $\beta 1 \neq 0$. Hal ini menunjukkan bahwa semakin baik kompetensi sumber daya manusiamaka kualitas laporan keuangan suatuPemerintah Daerah akan semakin baik pula. Penelitian secara parsial menunjukkan bahwa kompetensi SDM memiliki nilai sebesar 0,361, hal ini menunjukkan bahwa setiap terjadi peningkatan pada kompetensi sumber daya manusiadalam skala interval akan meningkatkan kualitas laporan keuangan SKPD kota salatiga sebesar 0,361 satuan pada skala interval. Dalam kolom coeficients model 1 menunjukan bahwa nilai sig 0,045 . Ketika nilai sig lebih kecil dari nilai probabilitas 0,05 maka $\mathrm{H} 2$ diterima. Variabel Kopetensi SDM (X2) memiliki thitung sebesar 2,020 dan $t$ tabel sebesar 2,056. Disini thitung $>t$ tabel yang menunjukkan bahwa variabel X2 memiliki kontribusi terhadap variabel Y. X2 memiiki pengaruh signifikan positif terhadap $\mathrm{Y}$.

Hasil penelitian ini konsisten dengan hasil penelitian yang dilakkan oleh (Lasmara \& Rahayu, 2016)yang menunjukkanbahwa kompetensi SDM berpengaruh positif terhadapkualitas laporan keuangan pemerintah.

\section{c. Peran Auditor Internaldan Kualitas LaporanKeuangan Pemerintah Daerah}

Auditor internal adalah salah lini terdepan dalam proses pengawasan dan kunci keberhasilan Pemerintah Daerah. Keterlibatan seorang auditor internal dalam proses pengawasan kualitas laporan keuangan memiliki pengaruh positif terhadap kualitas pelaporan keuangan. Hipotesis ketigaditerima. Artinya, peran auditor internal memiliki pengaruh positif terhadap kualitas laporan keuangan. Sama halnya dengan fakta dan data yang diperoleh peneliti bahwa peran audit internal berpengarh terhadap kualitas laporan keuangan.

Hasil pengujian hipotesis menunjukkan bahwa nilai koefisien regresi $\beta 1 \neq 0$. Hal ini menunjukkan bahwa semakin baik peran auditor internal maka kualitas laporan keuangan suatuPemerintah Daerah akan semakin baik pula. Penelitian secara parsial menunjukkan bahwa peran audit internal memiliki nilai sebesar $-0,546$, hal ini menunjukkan bahwa setiap terjadi peningkatan pada peran audit internal dalam skala interval akan meningkatkan kualitas laporan keuangan SKPD kota salatiga sebesar -0,546 satuan pada skala interval. Dalam kolom coeficients model 1 menunjukan bahwa nilai sig 0,008. Ketika nilai sig lebih kecil dari nilai probabilitas 0,05 maka H3 diterima. Variabel Peran audit internal (X3) 
memiliki t hitung sebesar $-2,889$ dan $\mathrm{t}$ tabel sebesar 2,056 . Disini $t_{\text {hitung }}>t_{\text {tabel }}$ yang menunjukkan bahwa variabel X3 memiliki kontribusi terhadap variabel Y. X3 memiiki pengaruh signifikan negatif terhadap Y.

Hasil penelitian ini konsisten dengan hasil penelitian yang dilakukan oleh(Gros et al., 2017) (Gras-Gil et al., 2012) (Abbott et al., 2016) (Suherman, 2018) (Erfiansyah \& Kurnia, 2018) (Johl et al., 2013) menunjukkan bahwa auditor internal berpengaruh terhadap kualitas laporan keuangan pemerintah. Karena ketika internal auditor telah menjalankan tugas pokok dan fungsinya berarti, secara subtansi entitas atau lembaga tersebut telah melakukan pencegahan dan antisipasi dini atas tindakan kesalahan maupun kecurangan.

\section{KESIMPULAN}

Berdasarkan hasil analsis data dapat diambil kesimpulan bahwa 1) Penerapan Stadar Akuntansi Pemerintahan (SAP), kompetensi Sumber Daya Manuasia (SDM) maupun Peran Auditor Internal berpengaruh terhadap kualitas laporan keuanganPemerintah Daerah kota Salatiga. Dalam terdapat perbedaan dengan penelitian lain, dapat disebabkan oleh factor lain diluar variable penelitian. Guna menjamin kualitas laporan keuangan secara umum, pemenuhan tifa faktor sebagaimana variable independen dalam penelitian ini sangat disarankan.

\section{UCAPAN TERIMA KASIH}

Pertama-tama kami ucapkn banyak terima kasih kepada Allah SWT atas segala nikmat dan karunianya. Semua pihak yang terlibat langsungmaupun tak langsung dalam penelitian ini termasuk para pejabat dan staf dilingkungan pemerintah kota Salatiga. Berkat bantuan dari selruh pihak, maka penelitian ini dapat terselesaikan dengan bak.

\section{REFERENSI}

Abbott, L. J., Daugherty, B., Parker, S., \& Peters, G. F. (2016). Internal Audit Quality and Financial Reporting Quality: The Joint Importance of Independence and Competence. Journal of Accounting Research, 54(1), 3-40. https://doi.org/10.1111/1475-679X.12099

Amalia, S. R. N., \& Lukito, H. (2014). Pengaruh Auditor Internal Terhadap Kualitas Pelaporan Keuangan Pada Bank Perkreditan Rakyat Di Jawa Tengah. Diponegoro Journal of Accounting, 3(2), 01-10.
BPKP. (2010). BPKP Gelar Kongres Peningkatan Kualitas Laporan Keuangan Pemerintah Daerah dan Bimbingan Teknis Bagi Administrator SIMDA.

Du, X., Yin, J., \& Hou, F. (2018). Auditor human capital and financial misstatement: Evidence from China. China Journal of Accounting Research, 11(4), 279-305. https://doi.org/10.1016/j.cjar.2018.06.001

Erfiansyah, E., \& Kurnia, I. (2018). Peranan Auditor Internal Terhadap Kualitas Pelaporan Keuangan. Jurnal Ilmiah Manajemen, Ekonomi, \& Akuntansi (MEA), 2(2), 144-160. https://doi.org/10.31955/jimea.vol2.iss2.pp144160

Fikri, D. A., Made, A., \& Wirshandono, D. (2016). Pengaruh Kompetensi Sumber Daya Manusia, Penerapan Sistem Pengendalian Intern Pemerintah dan Standar Akuntansi Pemerintah Terhadap Kualitas Laporan Keuangan Pemerintah Daerah. Journal Riset Mahasiswa Akuntansi (JRMA), 4(2), 21-40.

Gras-Gil, E., Marin-Hernandez, S., \& de Lema, D. G. P. (2012). Internal audit and financial reporting in the Spanish banking industry. Managerial Auditing Journal, 27(8), 728-753. https://doi.org/10.1108/02686901211257028

Gros, M., Koch, S., \& Wallek, C. (2017). Internal audit function quality and financial reporting: results of a survey on German listed companies. Journal of Management and Governance, 21(2), 291-329. https://doi.org/10.1007/s10997-0169342-8

Johl, S. K., Kaur Johl, S., Subramaniam, N., \& Cooper, B. (2013). Internal audit function, board quality and financial reporting quality: Evidence from Malaysia. Managerial Auditing Journal, 28(9), 780-814. https://doi.org/10.1108/MAJ06-2013-0886

Kurniawan, A. (2015). Audit Internal: Nilai Tambah Bagi Organisasi. Yogyakarta: BPFE.

Lasmara, F., \& Rahayu, S. (2016). Pengaruh Kompetensi Sumberdaya Manusia, Perangkat Pendukung dan Peran Auditor Internal terhadap Kualitas Laporan Keuangan Pemerintah Daerah Kabupaten Kerinci. Jurnal Perspektif Pembiayaan Dan Pembangunan Daerah, 3(4), 231-242.

Mardiasmo. (2018). Akuntansi Sektor Publik. Yogyakarta: Andi Offset. 
Jurnal Akuntansi dan Pajak, 21 (02), 2021, 481

Munasyir. (2015). Pengaruh Penerapan Standar Akuntansi Pemerintahan dan Sistem Pengendalian Intern Pemerintah Terhadap Kualitas Laporan Keuangan Satuan Kerja Pemerintah Daerah di Kabupaten Aceh Utara. Jurnal Magister Akuntansi Pascasarjana Universitas Syiah Kuala, 4(4), 23-35. https://doi.org/2302-0164

Peraturan Pemerintah. Pengelolaan Keuangan Daerah Nomor 58 Tahun 2005. , (2005).

Peraturan Pemerintah. Standar Akuntansi Pemerintahan No. 71 Tahun 2010. , (2010).

Pinto, I., Morais, A. I., \& Quick, R. (2020). The impact of the precision of accounting standards on the expanded auditor's report in the European Union. Journal of International Accounting, Auditing and Taxation, 40, 1-18.

Sako, U., \& Lantowa, F. D. (2018). Pengaruh Penerapan Standar Akuntansi Pemerintahan Terhadap Kualitas Penyajian Laporan Keuangan Pada Pemerintah Kabupaten Gorontalo. Journal of Accounting Science, 2(1), 43-54. https://doi.org/10.21070/jas.v2i1.1101
Sudarmanto. (2015). Kinerja dan Pengembangan Kompetensi SDM (3rd ed.). Yogyakarta, Indonesia: Pustaka Pelajar.

Sugiyono. (2017). Metode Penelitian Kuantitatif, Kualitatif, dan R\&D. Bandung: CV. Alfa Beta.

Suherman, A. (2018). Pengaruh Audit Internal Terhadap Kualitas Pelaporan Keuangan. Jurnal Pendidikan Akuntansi \& Keuangan, 6(2), 87. https://doi.org/10.17509/jpak.v6i2.15917

Wineh, S., Ferdian, T., \& Novianti. (2019). Faktor Yang Mempengaruhi Kualitas Laporan Keuangan Dengan Sistem Pengendalian Intern Sebagai Variabel Moderasi ( Studi Kasus Pada Organisasi Perangkat Daerah Kabupaten Merangin, Jambi). Jurnal DINAMIKA, 5(1), 6384.

Yusniyar, Darwanis, \& Abdullah, S. (2016). Pengendalian Intern Terhadap Good Governance Dan Dampaknya Pada Kualitas Laporan Keuangan. Jurnal Magister Akuntansi Pascasarjana Syiah Kuala, 5(2), 100-115. 